\title{
PENGGUNAAN BAHAN TAMBAHAN PANGAN ALAMI SEBAGAI PANGAN SEHAT PADA "LAUK TULANG LUNAK ISLAMI" HALALAN THAYYIBAN
}

\author{
Anny Sartika Daulay'), Muhammad Hizbullah' ${ }^{2)}$ \\ Universitas Muslim Nusantara Al-Washliyah ${ }^{1)}$ \\ Universitas Muslim Nusantara Al-Washliyah²)
}

\begin{abstract}
ABSTRAK
Ibu-ibu Muallaf di sekitar Desa Amplas Kecamatan Percut Sei Tuan Kabupaten Deli Serdang merupakan bagian daripada ibu rumah tangga yang tergolong dalam perempuan dengan emansipasi wanita. Kelompok Ibu-ibu Muallaf ini terdiri dari 1 (satu) Ketua dan 2 (dua) orang anggota. Permasalahan yang dihadapi mitra kelompok ibu-ibu muallaf ini adalah kurangnya kepercayaan masyarakat terhadap produk makanan yang dihasilkan. Hal ini tercermin dari pelanggan pecal ulek ibu tersebut merupakan komunitas masyarakat agama lain. Maka keadaan ekonomi keluarga ibu-ibu ini tetap dalam ekonomi lemah. Produk Lauk Tulang Lunak Mix Sayur Pecal Ulek Islami Halalan dan Thayyiban yang dihasilkan harus memenuhi parameter kelayakan makanan sebagai minuman yang halal dan menyehatkan sesuai persyaratan yang ditentukan. Produksi usaha ini direncanakan dilakukan setiap hari. Lauk yang digunakan dapat berupa ayam, ikan lele atau ikan nila. Semua bahan lauk yang digunakan dalam keadaan segar. Lauk dan sayuran diolah dengan bumbu penyedap, pengawet, pewarna yang alami. Makanan yang dihasilkan dalam pengabdian ini halal dan menyehatkan. Hasil pengabdian PKM ini yang secara langsung dapat diterima oleh masyarakat adalah penambahan modal usaha dalam bentuk bahan dasar usaha pecel ulek dengan lauk ayam tulang lunak. Nilai penjualan yang dimulai dari Rp. 3000,- sekarang menjadi Rp. 10.000,- Penghasilan ibu muallaf ini dapat ditingkatkan menjadi Rp. 5000,- untuk tiap porsinya. Jika pada awal penjualan yang terjual sekitar 20 porsi, maka hasil yang merupakan keuntungan berkisar Rp. 100.000,- perharinya. Diharapkan usaha ini dapat berjalan dan terus berkembang sehingga penghasilan mitra dapat meningkat seiring dengan berjalannya waktu.
\end{abstract}

Kata kunci: lauk tulang lunak, pecal ulek islami, halalan thayyiban

\begin{abstract}
Mothers of Muallaf around Amplas Village, Percut Sei Tuan District, Deli Serdang Regency are part of housewives who are classified as women with female emancipation. The Mothers of Muallaf group consists of 1 (one) Chairman and 2 (two) members. The problem faced by the group of converting mothers is the lack of public trust in the food products they produce. This is reflected in the customer of the mother's pecal ulek being a community of other religions. So the economic situation of these mothers' families remains in a weak economy. The resulting soft bone side dishes of vegetable pecal Ulek Ulek Islami and Thayyiban must meet the parameters of food eligibility as a halal and healthy drink according to the specified requirements. The production of this business is planned to be carried out every day. The side dishes used can be chicken, catfish, or tilapia. All side dishes used are fresh. Side dishes and vegetables are processed with seasonings, preservatives, natural dyes. The food produced in this service is lawful and healthy. The result of this PKM service that was directly accepted by the community was the addition of business capital in the form of the basic ingredients for the pecel ulek business with soft bone chicken side dishes. Sales value starting from Rp. 3000, - is now Rp. 10,000, - The income of this convert mother can be increased to Rp. 5000, - for each portion. If at the beginning of the sale, about 20 portions were sold, then the profit would be around Rp. 100,000, - per day. It is hoped that this business can run and continue to grow so that partner income can increase over time.
\end{abstract}

Keywords: soft bone side dishes, Islamic pecal ulek, halalan thayyiban 


\section{PENDAHULUAN}

Pada era emansipasi wanita saat ini, peran perempuan sangat dibutuhkan untuk membantu memenuhi kebutuhan keluarga. Banyak diantara ibu rumah tangga dengan iklas mengerahkan segala tenaga dan keterampilannya untuk mendapatkan income tambahan. Penambahan pendapatan keluarga dimaksudkan untuk dalam memenuhi kebutuhan pangan seterusnya untuk peningkatan pendidikan anak sebagai penerus generasi keluarga dan bangsa Indonesia. Ibu rumah tangga sudah memahami perlunya pendidikan untuk masa depan putera puterinya.

Ibu-ibu Muallaf di sekitar Desa

Amplas Kecamatan Percut Sei Tuan Kabupaten Deli Serdang merupakan bagian daripada ibu rumah tangga yang tergolong dalam perempuan dengan emansipasi tadi. Mereka kokoh mempertahankan keyakinan yang telah dipilih dan memperjuangkan keberlangsungan keluarganya dan masa depan anak-anaknya.

Kelompok Ibu-ibu Muallaf ini terdiri dari 1 (satu) Ketua dan 2 (dua) orang anggota dimana keluarga mereka masih mengalami kesulitan ekonomi. Salah satu anggotanya merupakan ibu muallaf dan sekaligus janda yang masih mempunyai tanggungan. Ibu ini bekerja sebagai penjahit kodian dan penjual cemilan anak-anak siap saji. Kehidupan keluarga ini juga dalam keadaan prihatin, tetapi keteguhan imannya tidak berkurang.

Permasalahan yang dihadapi mitra kelompok ibu-ibu muallaf ini adalah kurangnya kepercayaan masyarakat terhadap produk makanan yang dihasilkan. Hal ini tercermin dari pelanggan pecal ulek ibu tersebut merupakan komunitas masyarakat agama lain. Sangat disayangkan jika kepercayaan masyarakat terhadap dagangan ibu-ibu tersebut tidak ditingkatkan maka keadaan ekonomi keluarga ibu-ibu ini tetap dalam ekonomi lemah.

Kondisi akan lebih baik jika penanganan perekonomian keluarga ibu- ibu muallaf ini dimulai dari akar permasalahan, masing-masing ibu muallaf mengembangkan usahanya dalam berjualan nasi yang dilengkapi dengan lauk dan sayur yang bercirikan islami. Kelompok ibu-ibu muallaf ini perlu dibekali keterampilan mengolah makanan dengan berbahan alami dan segar. Bumbu masakan menggunakan rempah-rempah dan langkok-langkok yang disiapkan sendiri. Pemanis menggunakan gula asli. Pengawet menggunakan asam, garam dan sterilisasi dengan pemanasan yang tinggi. Bahan masakan semuanya menggunakan bahan dasar alami, tidak satupun menggunakan bahan tambahan pangan kimia atau sintetis. Hal ini perlu dilakukan karena secara islami para pedagang haruslah menyuguhkan makanan yang sehat dan bergizi yang menyehatkan dan berguna bagi pembeli yang mengkonsumsinya. Ciri khas dagangan ibu-ibu muallaf ini diupayakan menjadi keunggulan dan ciri khas yang dicari konsumen karena dirasakan sebagai suatu kebutuhan. Dengan demikian nilai jual dari produk yang dihasilkan meningkat.

Permasalahan khusus dari ibu-ibu muallaf ini belum memahami hakikat makanan yang disebut halal dan thayyib. Dalam pengabdian ini kelompok ibu-ibu muallaf ini diajarkan, dilatih dan dididik untuk dapat menghasilkan produk makanan yang halal dan thayyib. Dengan demikian konsumen merasa yakin dengan makanan yang dibeli dan dikonsumsinya.

Makanan halal adalah segala sesuatu makanan yang dapat dikonsumsi oleh manusia dan diperbolehkan dalam syariat Islam serta makanan tersebut bukanlah makanan haram yang disebutkan oleh Allah dalam Al Quran. Makanan thayyiban merupakan makanan yang harus mengandung zatzat yang sangat diperlukan tubuh seperti protein, karbohidrat, vitamin-vitamin, lemah (HDL), dan mineral. Makanan yang halal dan thayyib sudah secara otomatis menjadi makanan sehat. 
Makanan sehat adalah makanan yang higienis serta banyak mengandung gizi.

Permasalahan prioritas adalah Mitra Ibu-ibu Muallaf ini semuanya merupakan ibu rumah tangga dengan tingkat ekonomi yang rendah. Ibu-ibu Muallaf ini tidak mengetahui cara membantu perekonomian keluarganya dan meningkatkan taraf hidup rumah tangganya. Ibu-ibu Muallaf ini terbelenggu dengan praduga masyarakat yang menganggap ibu-ibu ini kurang paham menghasilkan makanan yang halal dan thayyib.

\section{METODE PELAKSANAAN}

Langkah-langkah kegiatan pelatihan dapat dilakukan oleh tim Program Kemitraan Masyarakat (PKM) oleh staf pengajar Program studi Farmasi Universitas Muslim Nusantara Al-Washliyah dengan cara mengumpulkan para ibu Muallaf di suatu tempat untuk mengikuti bimbingan.

Metode tahapan pelaksanaan pengabdian masyarakat ini dilakukan sebagai berikut:

1. Ketua dan anggota tim pengusul mempersiapkan dan mendiskusikan program kerja yang akan dilakukan selama pelaksanaan pengabdian. Persiapan yang dilakukan dilanjutkan dengan persiapan peralatan dan bahan yang diperlukan.

2. Membuat kesepakatan dengan Mitra terhadap waktu merealisasikan kegiatan ini, direncanakan kegiatan dilaksanakan selama 6 bulan, dimulai dari bulan Agustus 2019 dan berakhir pada bulan Desember 2019. Selama 6 (enam) bulan waktu pelaksanaan, Mitra telah dapat mandiri dalam mengolah modal usaha dan telah mampu memasarkan usahanya secara berkesinambungan.

3. Sosialisasi makanan yang halal dan thayyib pada Mitra Ibu-ibu Muallaf.

4. Memberikan pemaparan materi cara produksi kepada Mitra mengenai Perencanaan produk yang akan dihasilkan pada PKM Penggunaan Bahan Tambahan Pangan Alami Sebagai Pangan Sehat Pada "Lauk Tulang Lunak Mix Sayur Pecal Ulek Islami" Halal Dan Thayyib sehingga Mitra memahaminya.

5. Melaksanakan pelatihan pembuatan produk Penggunaan Bahan Tambahan Pangan Alami Sebagai Pangan Sehat Pada "Lauk Tulang Lunak Mix Sayur Pecal Ulek Islami" Halal Dan Thayyib sehingga Mitra dapat memasarkannya.

6. Membuat promosi dalam bentuk spanduk dan brosur.

7. Mitra ibu-ibu Muallaf berpartisipasi secara langsung sebagai peserta yang diberikan ilmu pengetahuan, sosialisasi dan pelatihan/pembekalan sehingga dapat mengembangkan usaha dan berpeluang untuk menjadi sukses.

8. Mitra berpartisipasi dalam meluangkan waktu serta menyediakan tempat sesuai dengan kesepakatan.

9. Monitoring dan evaluasi dilakukan selama 3 (satu) tahun berikutnya untuk memastikan bahwa usaha Mitra masih berjalan dan mengalami peningkatan.

\section{HASILDAN PEMBAHASAN}

Hasil yang didapatkan dari kegiatan Pengabdian kepada Masyarakat ini Ibu-ibu Muallaf Desa Percut Sei Tuan mempunyai pengetahuan dan pemahaman menyiapkan masakan yang berbasis lauk dan daging segar menjadi makanan yang halalan Thayyiban. Ibuibu Muallaf ini juga mendapatkan tambahan informasi penggunaan bahanbahan alami sebagai Bahan Tambahan Makanan yang memberikan manfaat dan berkhasiat bagi kesehatan. Program pengabdian PKM ini juga sangat berguna bagi peningkatan pendapatan bagi ibu-ibu Muallaf sebagai Mitra Pengabdian PKM ini. 


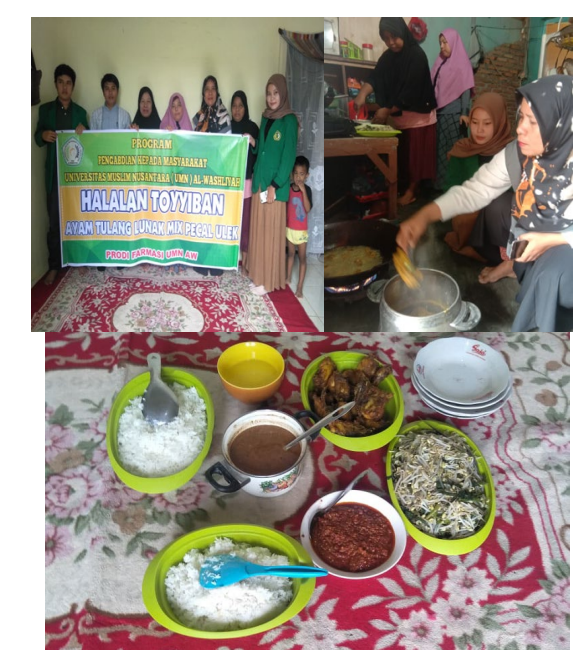

Gambar 1. Dokumentasi kegiatan PKM Dosen Farmasi

Kegiatan ini mendapatkan luaran berupa produk makanan halalan thayyiban, draft artikel ilmiah, publikasi di media offline (WASPADA) dan berupa video yang dipublikasikan di media online youtube dan diseminasi.

\section{KESIMPULAN}

Program kegiatan pengabdian masyarakat bagi ibu-ibu muallaf yaitu PKM Penggunaan Bahan Tambahan Pangan Alami Sebagai Pangan Sehat Pada Lauk Tulang Lunak Mix Sayur Pecal Ulek yang Islami, Halalan dan thayyiban dapat menambah pengetahuan dan keterampilan dalam menyediakan produk makanan siap saji yang bernilai ekonomis dengan mengaplikasikan ilmu agama dan kimia pangan. Pelatihan ini juga mampu meningkatkan pengetahuan ibu-ibu tentang pemanfaatan bahan-bahan alami sebagai bahan tambahan makanan yang sehat dan bermanfaat.

\section{REFERENSI}

Anonim ${ }^{1}$. 2016. https://dalam islam. com/makanan-dan-minuman/ makanan-halal/makanan-halal Supriadi C. 2011. http:// kriteriamakanan-halal-thoyyib.html. /2014/12/
Anonim $^{2}$. 2016. https://www.ejurnal.com/2013/09/syaratsyara t-makanan-sehat.html. 